\title{
Origin and evolution of chemical composition of mineral waters of Szczawno-Zdrój inferred from long-term variation of ionic ratios, Sudetes Mts. (SW Poland)
}

\author{
Anastasia Romanova ${ }^{1} \cdot$ Adam Porowski $^{1}$ (D) Tomasz Zielski ${ }^{2} \cdot$ Andrzej Dancewicz $^{3}$
}

Received: 24 June 2020 / Accepted: 9 April 2021 / Published online: 8 May 2021

(c) The Author(s) 2021

\begin{abstract}
The archival records of chemical composition of mineral waters in Szczawno-Zdrój spa were analyzed in terms of variation of ionic ratios to explain the possible source and origin of the major compounds dissolved in water and evolution of groundwater chemical composition in time. The analyzed data contained the longest available series of chemical records, dating back to 1962, and related to waters discharged by five main springs: Dąbrówka, Marta, Młynarz, Mieszko and Mieszko 14. The research showed that mineral waters in Szczawno-Zdrój belong to shallow meteoric $\mathrm{CO}_{2}$-rich, $\mathrm{Rn}$-containing groundwaters which form their chemical composition mainly through the interaction with aquifer rocks. Detailed analysis of long-term variation of ionic ratios revealed that (1) the carbonates weathering, mostly acid hydrolysis of limestones and dolomites, and (2) the ion exchange reactions with clay minerals, mainly the so-called natural softening, play a fundamental role in formation of the chemical composition of studied waters. Both processes are responsible for the occurrence of dominant ions in solution such as $\mathrm{Ca}^{2+}, \mathrm{Mg}^{2+}, \mathrm{Na}^{+}$, and $\mathrm{HCO}_{3}{ }^{-}$. The aluminosilicates hydrolysis occurs with variable extent, but plays rather secondary role in formation of chemical composition. The time distributions of major element concentrations in studied waters showed a characteristic "concave" shape, indicating the decrease in concentrations beginning in the 60s and ending around 2005-2010. Such "concave" shape trends are not reflected in time distribution of ionic ratios which strongly suggests the occurrence of a simple dilution of chemical composition of mineral waters by the influx of fresh water. The observed considerable fluctuations of chemical composition of mineral waters in Szczawno-Zdrój are most probably associated with climatic factors, namely: the increased amounts of atmospheric precipitation in particular periods of time and its seasonal distribution. Such influx of fresh waters reduces considerably mineralization of shallow groundwaters and directly increases springs discharge.
\end{abstract}

Keywords $\mathrm{CO}_{2}$-reach mineral waters $\cdot$ Ionic ratios $\cdot$ Long-term variation trend $\cdot$ Origin of chemical composition $\cdot$ Waterrock interaction

This article is a part of the Topical Collection in Environmental Earth Sciences on "Mineral and Thermal Waters" guest edited by Drs. Adam Porowski, Nina Rman and Istvan Forizs, with James LaMoreaux as the Editor-in-Chief.

Adam Porowski

adamp@twarda.pan.pl

1 Institute of Geological Sciences, Polish Academy of Sciences (ING PAN), Twarda 51/55, 00-818 Warsaw, Poland

2 Uzdrowiskowy Zakład Górniczy, Uzdrowisko Szczawno-Jedlina S.A., Szczawno Zdrój, Poland

3 Institute of Meteorology and Water Management-National Research Institute (IMGW-PIB), Podleśna 61, 01-673 Warsaw, Poland

\section{Introduction}

Szczawno-Zdrój is one of the oldest and the most known spas in Poland where $\mathrm{CO}_{2}$-rich mineral waters are discharged by the system of springs and used for curative drinking and bathing purposes. It is one of the four spas in Poland (others are: Krynica-Zdrój, Wysowa-Zdrój, Szczawnica) where natural mineral waters have special certificate of medicinal waters granted by the National Institute of Public Health-National Institute of Hygiene. The certificate is based on many years of medical investigations which demonstrate the healing properties of at least one of the pharmacologically active compounds contained in such water. The medicinal waters are available 
on the market, but not recommended for daily drinking as average natural mineral or spring waters.

The resources of curative (medicinal) mineral waters in Szczawno-Zdrój are connected with infiltration of meteoric waters of modern hydrological cycle in Carboniferous fissured formations. The waters are discharged by several groups of shallow springs. Due to low infiltration rate, the spring's discharges are also low, usually below $0.2 \mathrm{~m}^{3} / \mathrm{h}$ for individual spring (i.e., from 0.024 to $0.2 \mathrm{~m}^{3} / \mathrm{h}$ ). In such hydrogeological conditions, one of the most important problem connected with sustainable extraction of curative mineral waters is the maintenance of the long-term stability of water quality, its physicochemical properties and chemical composition. Especially changes in chemical composition affect directly the water's salinity, its taste, nutritional and curative properties (Drobnik and Latour 2006; Latour and Smętkiewicz 2012; Ignatov et al. 2014; Kiełczawa and Liber-Makowska 2017; Porowski et al. 2018). The mineral and curative waters are the primary resource in Poland, and each spring has established mining and protection areas to protect the water quality. However, the progressive environment pollution within the spa area and the adverse climate changes may affect the quality of mineral waters in recharge zone in relatively short period of time (Ciężkowski 1990; Kiełczawa et al. 2008; Kiełczawa and Liber-Makowska 2018; Liber-Makowska and Kiełczawa 2018). The role of stormy weather phenomena, short and intensive rainfalls and floods on the quality of mineral waters in Szczawno-Zdrój was also discussed in the example of flood in 1997 (Kiełczawa et al. 2008; Kiełczawa and Liber-Makowska 2017).

In this study, the long-term monitoring of the chemical composition of mineral waters in Szczawno-Zdrój spa was presented in terms of variation of selected ionic ratios. The longest available (dating back to 1962) series of archival records of chemical composition of mineral waters in Szczawno-Zdrój was taken to analysis. Such approach not only helped to better understand the temporary changes in concentration of major chemical compounds itself but also it shed light on the potential changes in the water-rock interaction trends. The processes of water interactions with rock-forming minerals presumably play the crucial role in the formation of chemical composition of mineral waters in the Sudetes Mts. and directly affect or ensure its stability in time (Ciężkowski 1990; Hounslow 1995; Porowski 2001a, b, 2007; Porowski and Dowgiałło 2009; Żaczek and Porowski 2017). The longterm analyses of selected ionic rations are also useful in determining potential changes in the dominant source of a given chemical compounds in studied groundwaters.

\section{Study area and hydrogeological settings}

The mineral water reservoir of Szczawno-Zdrój occurs within the Intra-Sudetic depression, which is one of the largest geological structures of the western part of the Sudetes Mts. (Fig. 1). This structure extends for about $70 \mathrm{~km}$ from NW to SE, reaching a maximum width of approximately $30 \mathrm{~km}$ from SW to NE. The Szczawno-Zdrój spa is located in the NE part of the Intra-Sudetic depression, between the Świebodzice basin and the crystalline gneiss arc of the Sowie Mts., which constitutes the oldest geological formation in this region. The occurrence of mineral water is connected first of all with the Lower Carboniferous sediments occurring in three main formations (i.e., Culm facies): Chwaliszów formation, Lubomin formation and Szczawno formation (Teisseyre 1966, 1969; Haydukiewicz et al. 1982; Nawrocki et al. 2017). The Chwaliszów formation, the oldest one, composed of thick-layered conglomerates interbedded by sandstones, forms the most NE part of the reservoir. The thickness of this formation reaches $2000-2500 \mathrm{~m}$. It occurs directly under the Quaternary sediments and has a few outcrops in the vicinity of Szczawno-Zdrój (Fig. 1). The Lubomin formation is composed mainly of thick bedded conglomerates intercalated by greywacke, mudstones and clays. The thickness of this formation varies from a few hundred meters to about $3000 \mathrm{~m}$. The Szczawno formation, the youngest facies of the Lower Carboniferous in the vicinity of Szczawno-Zdrój, is composed of cyclically arranged layers of conglomerates, graywacke and mudstones. The characteristic feature is low-grained conglomerates and large contribution of mudstones beds reaching thickness of several dozen meters. The overall thickness of the Szczawno formation reaches 300-400 m. The Upper Carboniferous is represented by Wałbrzych formation and Biały Kamień formation; however, they occur in the southern part of the Szczawno-Zdrój, outside of the mining area of the mineral water reservoir.

From hydrogeological point of view, the Upper and the Lower Carboniferous formations belong to low permeable. The occurrence of mineral waters of Szczawno-Zdrój is connected with fissures and deep dislocations. Due to low infiltration rate into the Lower Carboniferous strata, the groundwater resources are small, and springs are characterized by low discharge rates from 0.02 to $0.5 \mathrm{~m}^{3} / \mathrm{h}$. Particular outflows of mineral waters used in Szczawno-Zdrój spa for drinking and curative purposes are in fact groups of several natural self-flowing springs enclosed with gastight and waterproof bells mounted directly on the Lower Carboniferous host rocks. They are located in resort cellars and some of them are extracted since 1912 (Fistek et al. 1975; Ciężkowski 1990; Przylibski et al. 2001). Actually, the studied sampling sites consist of the following number 


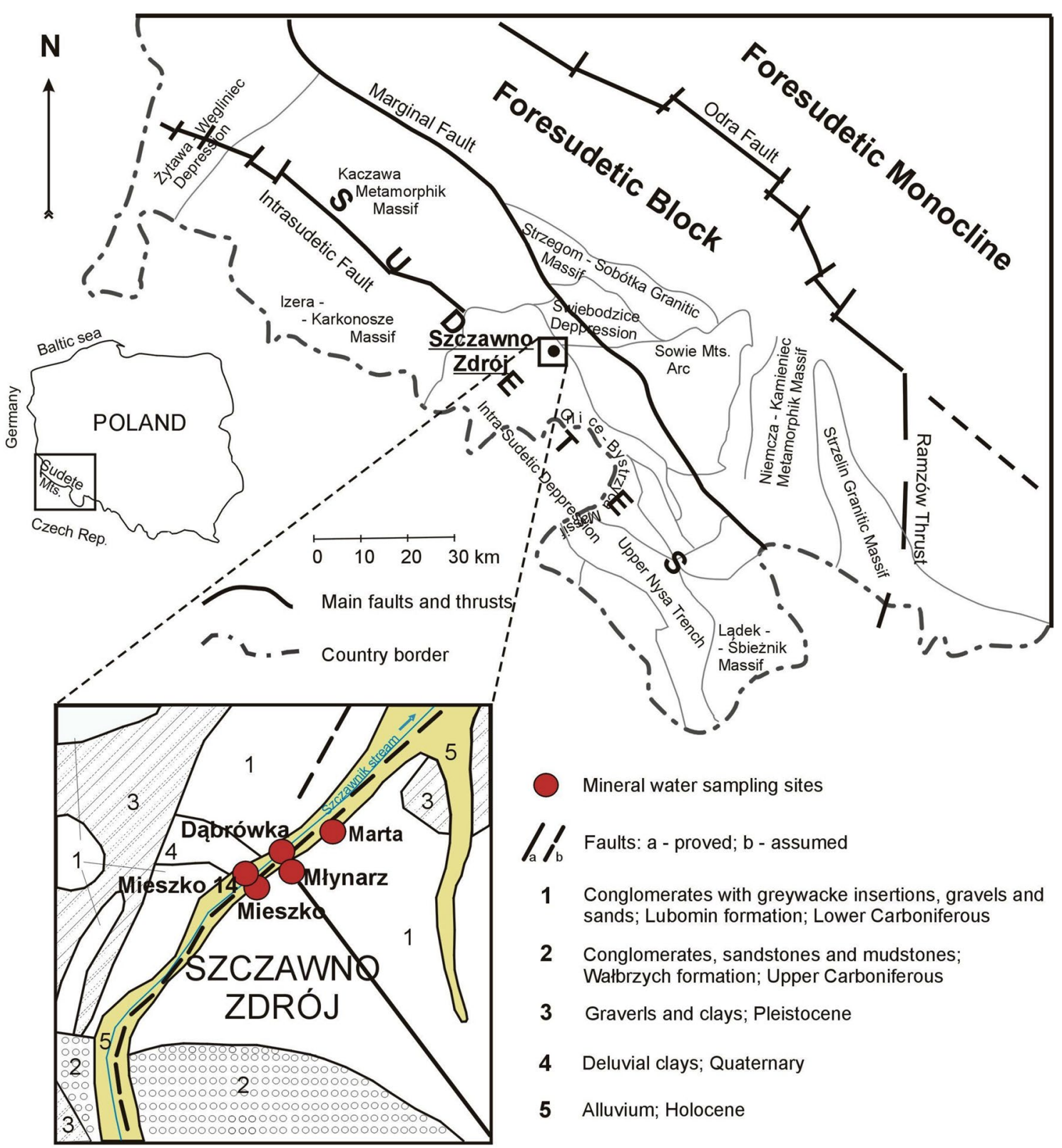

Fig. 1 Location of the study area and position of mineral water sampling sites in the schematic view of geological settings

of small springs and outflows: the Dąbrówka spring consists of 4 outflows, the Marta spring-9 outflows, the Mieszko spring-9 outflows, the Młynarz spring-5 outflows, and the Mieszko 14 spring-3 outflows (Table 1). The mineral water resources originate from infiltration of meteoric waters of modern hydrological cycle which circulate in fissured poorly permeable Lower Carboniferous sediments. One of the most prominent dislocations in this area is the tectonic zone of Struga which extends in NW-SE direction and reaches the fault of Szczawnik (Fig. 1). This intersection zone sets up the most favorable conditions for the outflow of this waters to the surface (Teisseyre 1966; Fistek et al.
1972, 1975; Ciężkowski 1990; Kiełczawa et al. 2008). The mineral waters of Szczawno-Zdrój are actually characterized by the total dissolved solids (TDS) values in the range of $2.0-3.9 \mathrm{~g} / \mathrm{dm}^{3}$, the $\mathrm{CO}_{2}$ content in the range of $0.6-2.1 \mathrm{~g} /$ $\mathrm{dm}^{3}$ (Table 2, data for 2018) and radon ( $\mathrm{Rn}$ ) content up to $326 \mathrm{~Bq} / \mathrm{dm}^{3}$. The $\mathrm{CO}_{2}$ found in these waters is commonly considered as a product of Tertiary volcanism, confirmed by the isotopic composition of $\mathrm{CO}_{2}$ carbon $\delta^{13} \mathrm{C}$ and geochemical studies of Upper Carboniferous coal-bearing series (Dowgiallo 1978; Kotarba 1988). The $\mathrm{CO}_{2}$ is presumably the main factor determining the water-rock interaction and the chemical composition of mineral waters studied. 


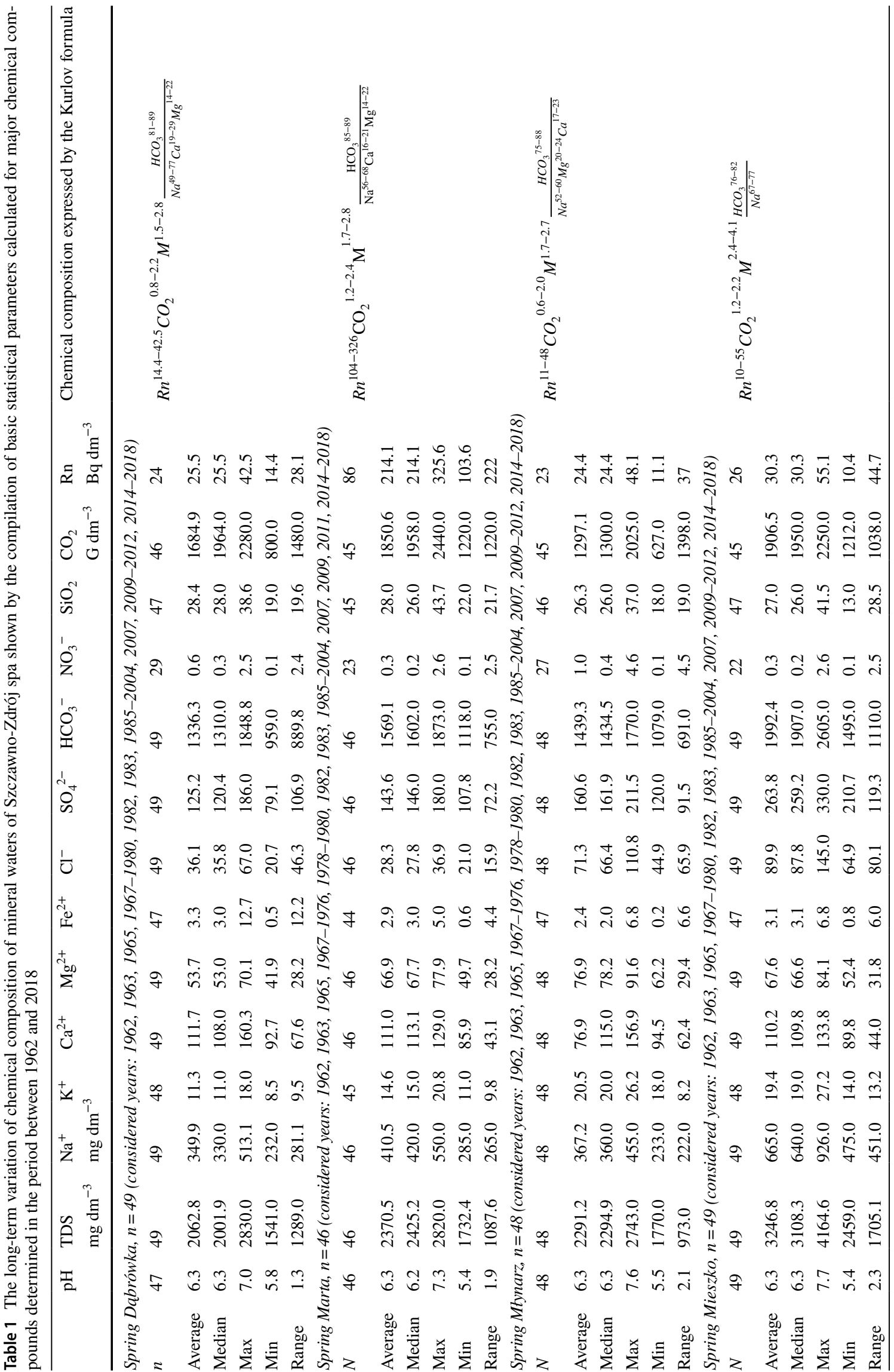



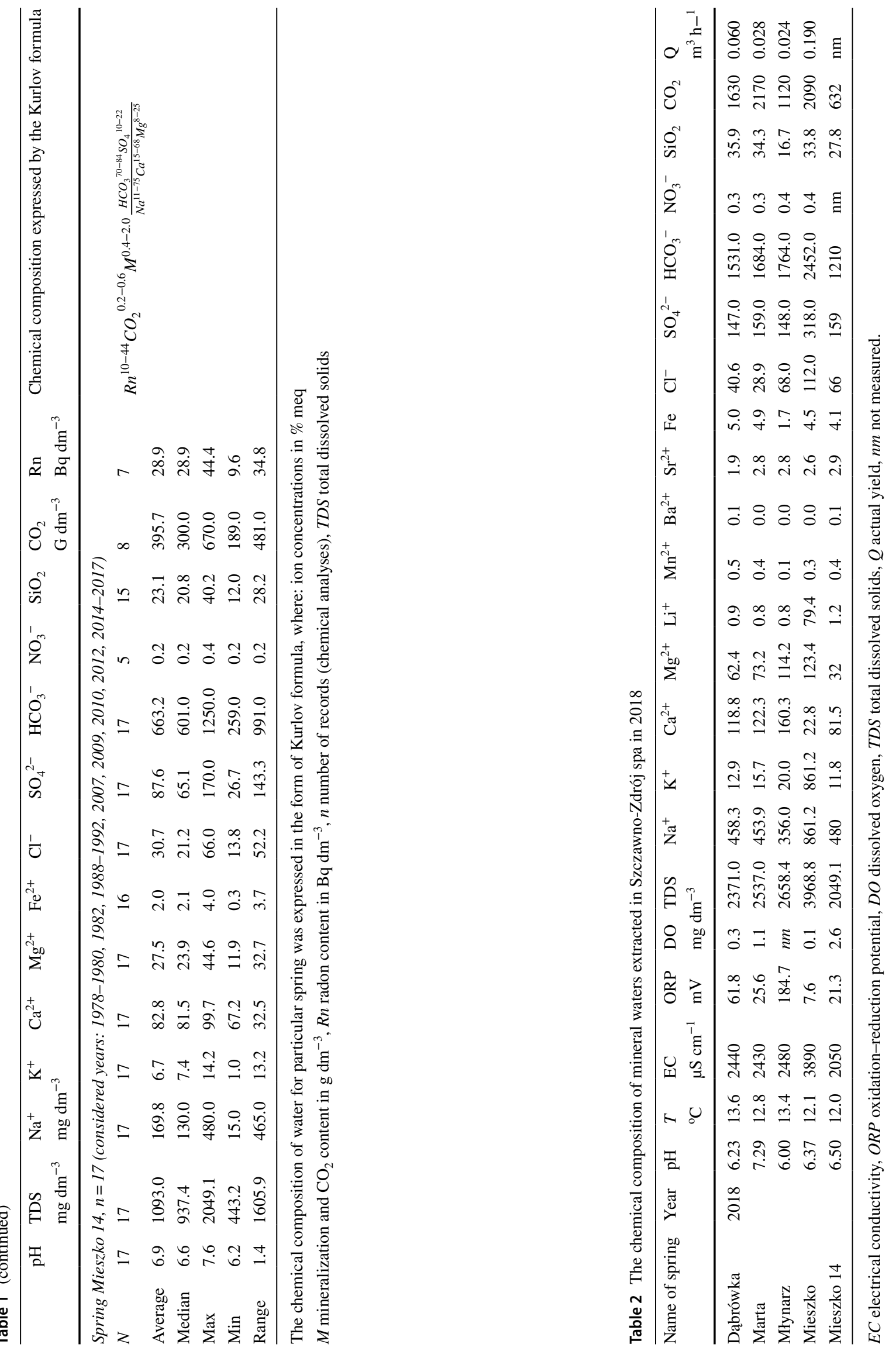


\section{Materials and methods}

The research is focused on the detailed interpretation of the long-term variation of the chemical composition of mineral waters discharged in Szczawno-Zdrój spa from 5 main sampling sites, namely: Dąbrówka, Marta, Młynarz, Mieszko and Mieszko 14. The archival records of chemical analyses of mineral waters from theses springs in the years from 1962 to 2017 were provided by the Hydrogeological Section of the Szczawno-Zdrój spa, namely "Uzdrowisko Szczawno-Jedlina" S.A. These records are official chemical analyses of mineral waters made by the spa once a year in certified chemical laboratories in Poland, such as "BP i UTBU Balneoprojekt" or the Central Mining Institute (from 90s up to date). Table 1 shows compilation of chemical compositions of the studied mineral waters in the form of Kurlov formulas and basic statistical parameters calculated for each measured chemical compound. The chemical compositions of all mineral waters within studied period are also plotted in Piper diagram (Fig. 3).

In 2018, the same springs of mineral waters in Szczawno-Zdrój were sampled to obtain the newest chemical analyses for comparison purposes. The results are presented in Table 2. During sampling campaign in 2018, the field measurements were made of basic physicochemical water quality parameters such as temperature $(T), \mathrm{pH}$, electrical conductivity (EC), and oxygen/ reduction potential (ORP), using an in-line flow-through cell, and portable meters such as a HQ40D multi meter (Hach $^{\circledR}$ GMBH, Germany) equipped with Intellical ${ }^{\mathrm{TM}}$ (Hach ${ }^{\circledR}$ GMBH, Germany) pH, EC, and ORP electrodes with temperature sensors. The EC and ORP values were used to determine when formation-quality water was available for sample collection (Nielsen and Nielsen 2006). For chemical analysis, water was filtered through $0.45 \mu \mathrm{m}$ syringe filters (MF-Millipore Membrane Millex ${ }^{\circledR}$ ) and collected in polyethylene bottles of $100 \mathrm{ml}$ and $30 \mathrm{ml}$ capacity for anions and cations determination; bottles for cations analyses were pre-acidified with ultra-pure $\mathrm{HNO}_{3}$. Then, samples were put into a portable fridge and delivered to the laboratory. The chemical analyses of mineral waters were performed at the Chemical Laboratory of the Polish Geological Institute-National Research Institute in Warsaw, Poland. A HPLC method (High-Performance Liquid Chromatography) was used for major anion analysis (except bicarbonates), and the ICP-OES method (Inductively Coupled Plasma Optical Emission Spectrometry) was used for cation analysis. Uncertainties in the determination of major ions, as reported by the laboratory, were in the range of $5-10 \%$. Bicarbonates were determined by the potentiometric titration method. The anion-cation charge balance method was followed to assess the accuracy of the chemical analyses: for all water samples, the charge balance was less than $5 \%$.

Selected ionic ratios were calculated and their temporal variations were analyzed to deduce the source rocks and geochemical processes that may be responsible for the origin of major chemical compounds.

\section{Results and discussion}

The long-term variation of chemical composition and physicochemical properties of mineral waters in Szczawno-Zdrój spa was observed in 5 springs. Table 1 shows compilation of the chemical compositions of studied mineral waters in the form of Kurlov formulas. To show the characteristic features and the range of the long-term variation of the chemical composition of studied waters, the basic statistical parameters were calculated for each measured chemical compound. The longest observed period reached 46-49 years for springs Dąbrówka, Marta, Młynarz and Mieszko, and the shortest, 17 years, for spring Mieszko 14 that supplies the least mineralized water and is used not regularly. The long-term variations of major chemical compounds were presented in Fig. 2.

Mineral waters in Szczawno-Zdrój spa belong generally to three hydrochemical types that differ in the total dissolved solids (TDS). The water extracted by shallowest spring Mieszko 14 revealed the lowest TDS values in the range of $0.4-2.0 \mathrm{~g} \mathrm{dm}^{-3}$ and the largest variation in chemical composition resulting in change of hydrochemical type of water several times within the whole observation period. At the beginning, the waters belonged to $\mathrm{HCO}_{3}-\mathrm{Na}-\mathrm{Ca}$ type; in the end of $80 \mathrm{~s}$, the waters changed to $\mathrm{HCO}_{3}-\mathrm{Ca}-\mathrm{Mg}$ and $\mathrm{HCO}_{3}-\mathrm{Ca}$ type observed in 1991 , through $\mathrm{HCO}_{3}-\mathrm{SO}_{4}-\mathrm{Ca}-\mathrm{Mg}$ in $2007-2009$, to $\mathrm{HCO}_{3}-\mathrm{Na}-\mathrm{Ca}$ in the last decade and $\mathrm{HCO}_{3}-\mathrm{Na}$ in 2017 with TDS being around $2.0 \mathrm{~g} \mathrm{dm}^{-3}$ (Tab. 2).

The water extracted by spring Mieszko belongs to $\mathrm{HCO}_{3}-\mathrm{Na}$ type and reveals the highest TDS values in the range of $2.5-8.9 \mathrm{~g} \mathrm{dm}^{-3}$. The mineralization observed in 2018 was around $3.9 \mathrm{~g} \mathrm{dm}^{-3}$ (Table 2). The waters extracted by springs Dąbrówka, Marta and Młynarz belong to $\mathrm{HCO}_{3}-\mathrm{Na}-\mathrm{Ca}-\mathrm{Mg}$ and $\mathrm{HCO}_{3}-\mathrm{Na}-\mathrm{Mg}-\mathrm{Ca}$ hydrochemical facies and showed intermediate TDS values in the range from 1.3 to $3.3 \mathrm{~g} \mathrm{dm}^{-3}$. In 2018, waters of these springs showed very similar TDS values in the narrow range from 2.3 to $2.6 \mathrm{~g} \mathrm{dm}^{-3}$ (Table 2). The $\mathrm{pH}$ values for all studied waters range between 5.4 and 7.7, with average values around 6.3-6.9. Such values indicate groundwaters containing variable amounts of $\mathrm{CO}_{2}$ gas, which is abundant in the gas phase of the studied mineral waters. The $\mathrm{pH}$ values higher than 7.0 suggest the variable influence of buffering reactions with carbonates or other rock-forming minerals during groundwater circulation. 

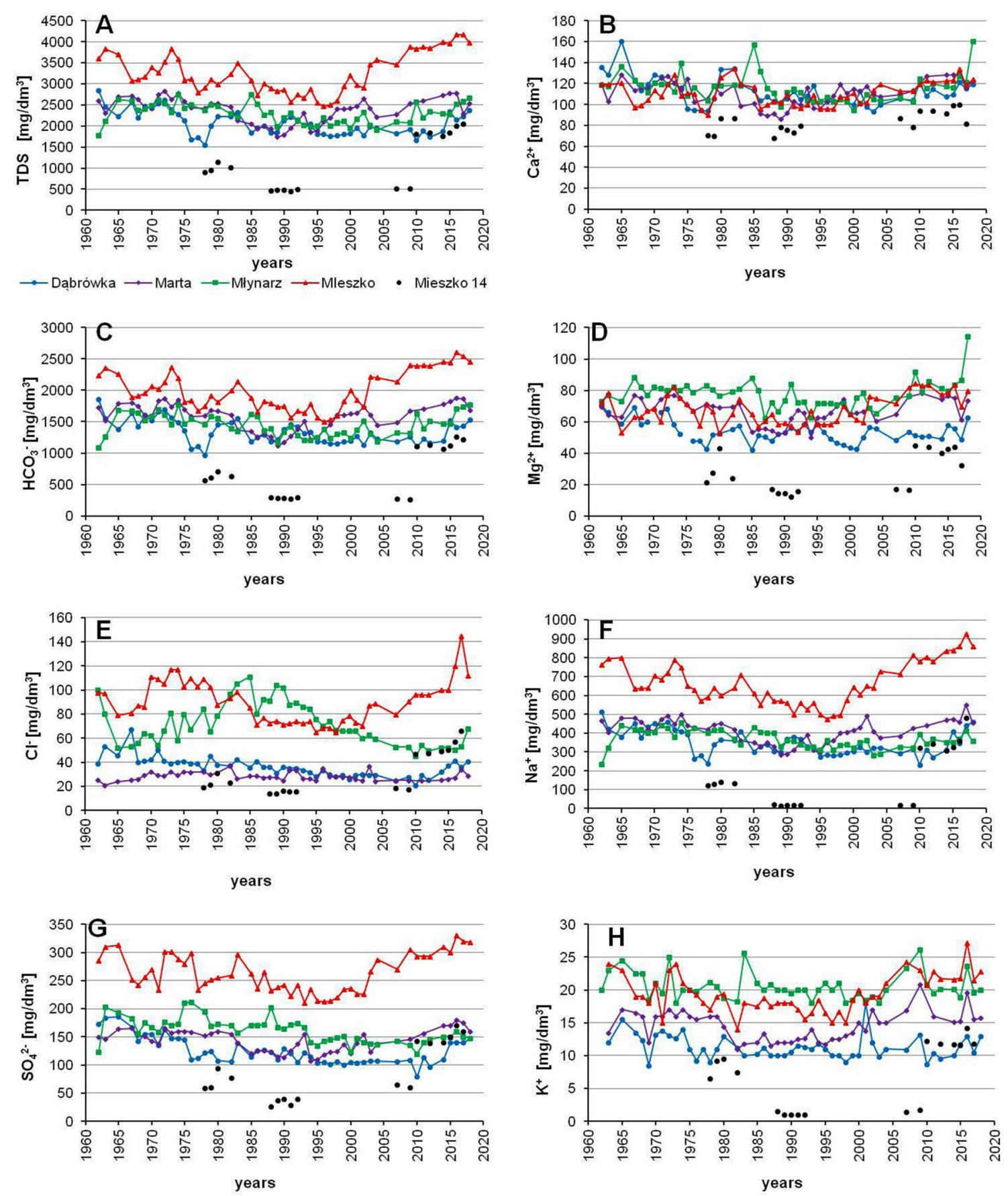

Fig. 2 Long-term variation of TDS and major chemical compounds in mineral waters of Szczawno-Zdrój spa for available data (1962-2018)

The chemical compositions of mineral waters extracted by all studied springs are compared in the Piper diagram presented on Fig. 3.

As can be seen on Piper diagrams, the chemical compositions of all studied waters, except water from spring Mieszko 14, were similar during the whole observation period and fell mainly into the zone for waters of $\mathrm{HCO}_{3}-\mathrm{Na}+\mathrm{K}$ type, indicating predominance (i.e., $>50 \%$ meq $/ \mathrm{dm}^{3}$ ) of bicarbonate and alkali metal ions. On the other hand, water from the shallowest spring Mieszko 14 showed significant fluctuations in chemical composition between waters of $\mathrm{HCO}_{3}-\mathrm{Na}+\mathrm{K}$ and $\mathrm{HCO}_{3}-\mathrm{Mg}-\mathrm{Ca}$ types. Water from spring Dąbrówka change significantly its chemical composition only occasionally, less than three times during the whole observation period. 

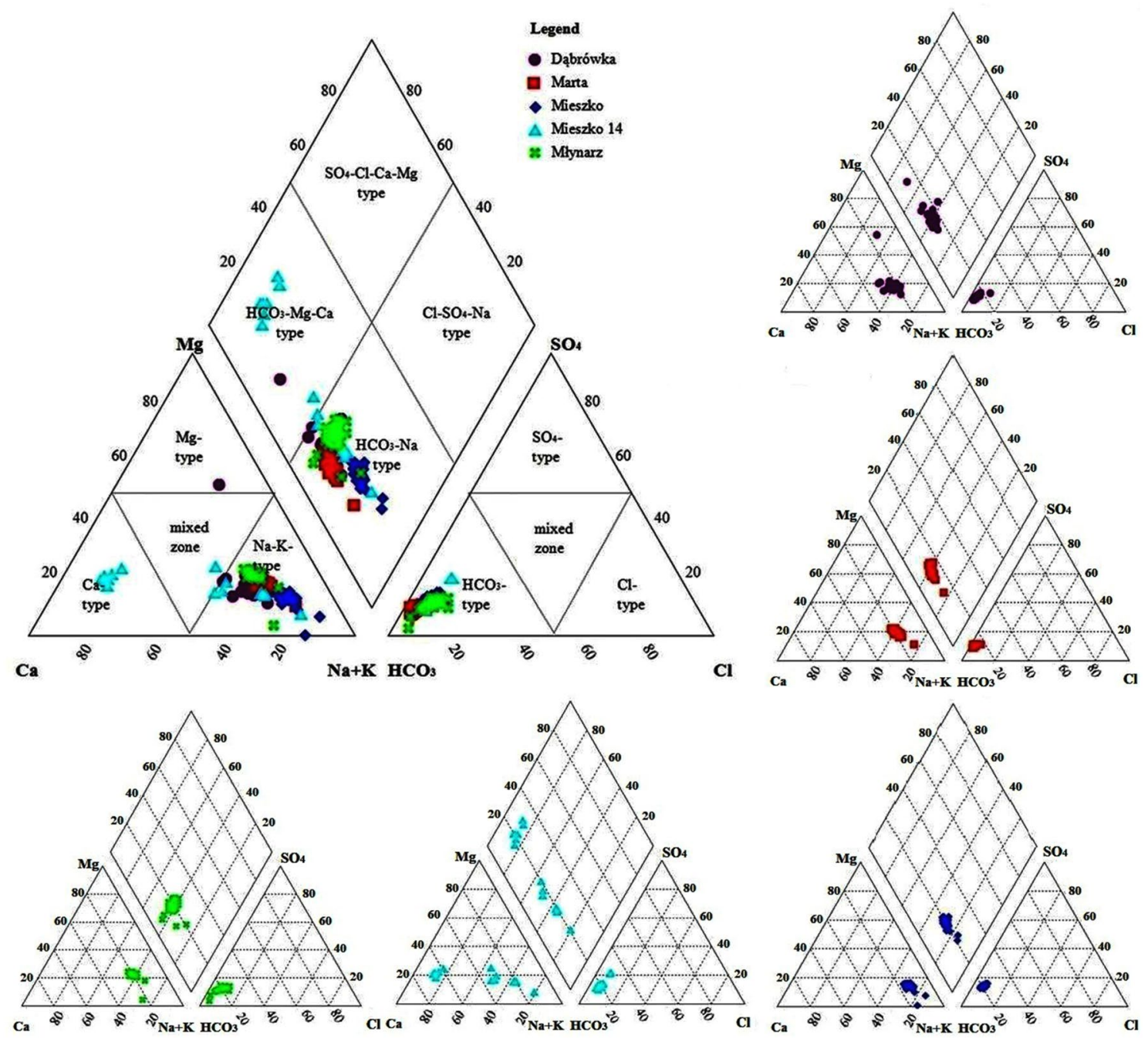

Fig. 3 Chemical composition of mineral waters of Szczawno-Zdrój spa shown on the Piper diagrams

\section{Variation of ionic ratios and origin of chemical composition}

A detailed analysis of selected ionic ratios was performed to determine the source of major ions dissolved in water and the origin of the chemical composition of the groundwater studied. The ionic ratios are usually applied to hydrogeochemical characterization of groundwater, to source rock deduction or prospecting for mineral deposits (Collins 1975; Hem 1989; Hounslow 1995; Porowski 2001a, b, 2006a; Macioszczyk and Dobrzyński 2007; Żaczek and Porowski 2017; Vinograd and Porowski 2020). Table 3 shows the ratios of major ions calculated and applied in this study. To better understand the trends of evolution of the chemical composition of studied mineral waters, the variation of ionic rations over time was calculated and compared in Fig. 4.

Various elemental ratios in groundwaters resulting from the weathering of some common rock-forming minerals leaving clay minerals on the product side. The common weathering process may be schematically shown as follows (Hounslow 1995):

$$
\begin{gathered}
\text { Rock-forming minerals }+a \mathrm{CO}_{2}+b \mathrm{H}_{2} \mathrm{O} \\
\rightarrow \text { clay }+ \text { cations }+c \mathrm{HCO}_{3}^{-}+d \mathrm{SiO}_{2} .
\end{gathered}
$$

The chemical composition of studied waters, which is characterized first of all by very low concentration of conservative $\mathrm{Cl}^{-}$(in the range of $13.8-145 \mathrm{mg} \mathrm{dm}^{-3}$ ) and relatively high concentration of $\mathrm{HCO}_{3}{ }^{-}$(in the range of 259.0-2605.0 $\mathrm{mg} \mathrm{dm}^{-3}$ ) confirms that the rock weathering may be the main process responsible for the origin of the major compounds.

Bicarbonate-silica ratio $\mathrm{m}\left[\mathrm{HCO}_{3}{ }^{-} / \mathrm{SiO}_{2}\right]$, expressed in mmol $\mathrm{dm}^{-3}$, can be used to distinguish between carbonate and silicate weathering (Hounslow 1995). Bicarbonate is formed when $\mathrm{CO}_{2}$ and water react with various minerals 
Table 3 Basic statistical data calculated for selected ionic ratios in mineral waters of Szczawno-Zdrój

\begin{tabular}{|c|c|c|c|c|c|c|}
\hline \multirow[t]{2}{*}{$\begin{array}{l}\text { Statistical param- } \\
\text { eters }\end{array}$} & \multirow{2}{*}{$\begin{array}{l}\frac{\mathrm{HCO}_{3}^{-}}{\mathrm{SiO}_{2}} \\
\mathrm{Mmol} \mathrm{dm}\end{array}$} & \multirow{2}{*}{$\begin{array}{l}\frac{\mathrm{SiO}_{2}}{\mathrm{Na}^{+}+\mathrm{K}^{+}-\mathrm{Cl}^{-}} \\
\mathrm{Mmol} \mathrm{dm}\end{array}$} & \multirow{2}{*}{$\begin{array}{l}\frac{\mathrm{Na}^{+}+\mathrm{K}^{+}}{\mathrm{Cl}^{-}} \\
\mathrm{Meq} \mathrm{dm}{ }^{-3}\end{array}$} & \multirow{2}{*}{$\begin{array}{l}\frac{\mathrm{Mg}^{2+}}{\mathrm{Ca}^{2+}+\mathrm{Mg}^{2+}} \\
\text { Meq dm }\end{array}$} & \multirow{2}{*}{ 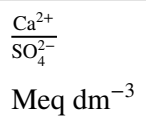 } & \multirow{2}{*}{$\begin{array}{l}\frac{\mathrm{SO}_{4}^{2-} \times 100}{\mathrm{Cl}^{-}} \\
\mathrm{Meq} \mathrm{dm}^{-3}\end{array}$} \\
\hline & & & & & & \\
\hline \multicolumn{7}{|c|}{ Dabrówka, $n=49(1962,1963,1965,1967-1980,1982,1983,1985-2004,2007,2009-2012,2014-2018)$} \\
\hline$n$ & 47 & 47 & 48 & 47 & 49 & 49 \\
\hline Average & 47.1 & 0.03 & 53.3 & 0.44 & 2.2 & 259.4 \\
\hline Median & 46.3 & 0.03 & 52.9 & 0.45 & 2.1 & 263.6 \\
\hline Max & 75.0 & 0.05 & 78.2 & 0.50 & 3.7 & 325.7 \\
\hline Min & 30.3 & 0.02 & 30.0 & 0.38 & 1.6 & 184.1 \\
\hline Range & 44.6 & 0.03 & 48.2 & 0.13 & 2.1 & 141.6 \\
\hline \multicolumn{7}{|c|}{ Marta, $n=46(1962,1963,1965,1967-1976,1978-1980,1982,1983,1985-2004,2007,2009,2011,2014-2018)$} \\
\hline$n$ & 45 & 45 & 45 & 46 & 46 & 46 \\
\hline Average & 56.1 & 0.03 & 60.8 & 0.50 & 1.9 & 380.7 \\
\hline Median & 53.5 & 0.03 & 61.2 & 0.50 & 1.8 & 375.3 \\
\hline $\operatorname{Max}$ & 80.5 & 0.04 & 86.1 & 0.55 & 2.3 & 513.5 \\
\hline Min & 40.1 & 0.02 & 44.9 & 0.44 & 1.5 & 248.9 \\
\hline Range & 40.4 & 0.02 & 41.2 & 0.10 & 0.8 & 264.6 \\
\hline \multicolumn{7}{|c|}{ Mtynarz, $n=48(1962,1963,1965,1967-1976,1978-1980,1982,1983,1985-2004,2007,2009-2012,2014-2018)$} \\
\hline$n$ & 46 & 46 & 48 & 48 & 48 & 48 \\
\hline Average & 55.2 & 0.03 & 16.2 & 0.53 & 1.7 & 174.1 \\
\hline Median & 53.6 & 0.03 & 15.6 & 0.53 & 1.7 & 170.3 \\
\hline Max & 104.1 & 0.04 & 25.4 & 0.57 & 2.6 & 273.5 \\
\hline Min & 38.9 & 0.02 & 7.0 & 0.47 & 1.2 & 90.8 \\
\hline Range & 65.2 & 0.03 & 18.3 & 0.10 & 1.4 & 182.7 \\
\hline \multicolumn{7}{|c|}{ Mieszko, $n=49(1962,1963,1965,1967-1980,1982,1983,1985-2004,2007,2009-2012,2014-2018)$} \\
\hline$n$ & 47 & 47 & 48 & 49 & 49 & 49 \\
\hline Average & 74.0 & 0.02 & 23.5 & 0.50 & 1.0 & 220.8 \\
\hline Median & 70.9 & 0.02 & 23.9 & 0.50 & 1.0 & 225.7 \\
\hline Max & 144.3 & 0.02 & 30.7 & 0.56 & 1.2 & 292.6 \\
\hline Min & 52.6 & 0.01 & 15.9 & 0.41 & 0.9 & 158.6 \\
\hline Range & 91.8 & 0.01 & 14.8 & 0.16 & 0.4 & 134.1 \\
\hline \multicolumn{7}{|c|}{ Mieszko 14, $n=17(1978-1980,1982,1988-1992,2007,2009,2010,2012,2014-2017)$} \\
\hline$n$ & 15 & 15 & 17 & 17 & 17 & 17 \\
\hline Average & 25.8 & 0.53 & 46.0 & 0.34 & 3.1 & 208.7 \\
\hline Median & 26.5 & 0.07 & 39.4 & 0.33 & 2.8 & 218.0 \\
\hline Max & 49.3 & 1.73 & 68.7 & 0.45 & 6.0 & 259.3 \\
\hline Min & 6.3 & 0.02 & 26.7 & 0.21 & 1.2 & 136.5 \\
\hline Range & 43.0 & 1.71 & 42.0 & 0.24 & 4.8 & 122.8 \\
\hline
\end{tabular}

in the processes called acid hydrolysis. Carbonates dissolve without releasing silica. The dissolution of silicates (e.g., albite, anorthite, orthoclase) releases considerable amounts of silica. The $\left[\mathrm{HCO}_{3}{ }^{-} / \mathrm{SiO}_{2}\right]$ ratio greater than 10 is usually considered as an indicator of carbonate dissolution and less than 5-as an indicator of silicates dissolution. As can be seen in Table 3, practically all mineral waters in Szczawno-Zdrój reveal this ratio greater than 10 ; only water from the shallowest spring Mieszko 14 reveals the lowest value around 6.3 in 2009. Waters from springs Dąbrówka, Marta, Młynarz and Mieszko have the
$\left[\mathrm{HCO}_{3}{ }^{-} / \mathrm{SiO}_{2}\right]$ ratio between 30 and 144 , which shows large advantage of the bicarbonate concentration over the silica in the chemical composition, and strongly suggests the predominance of the carbonates dissolution process over the silicates (Fig. 4). In low-temperature systems, carbonates, first of all calcite or dolomite, are known to be the most liable to dissolution and subsequent precipitation and recrystallization (Hounslow 1995; Appelo and Postma 1996). Typical chemical reactions of calcite and dolomite dissolution can be shown as following: 

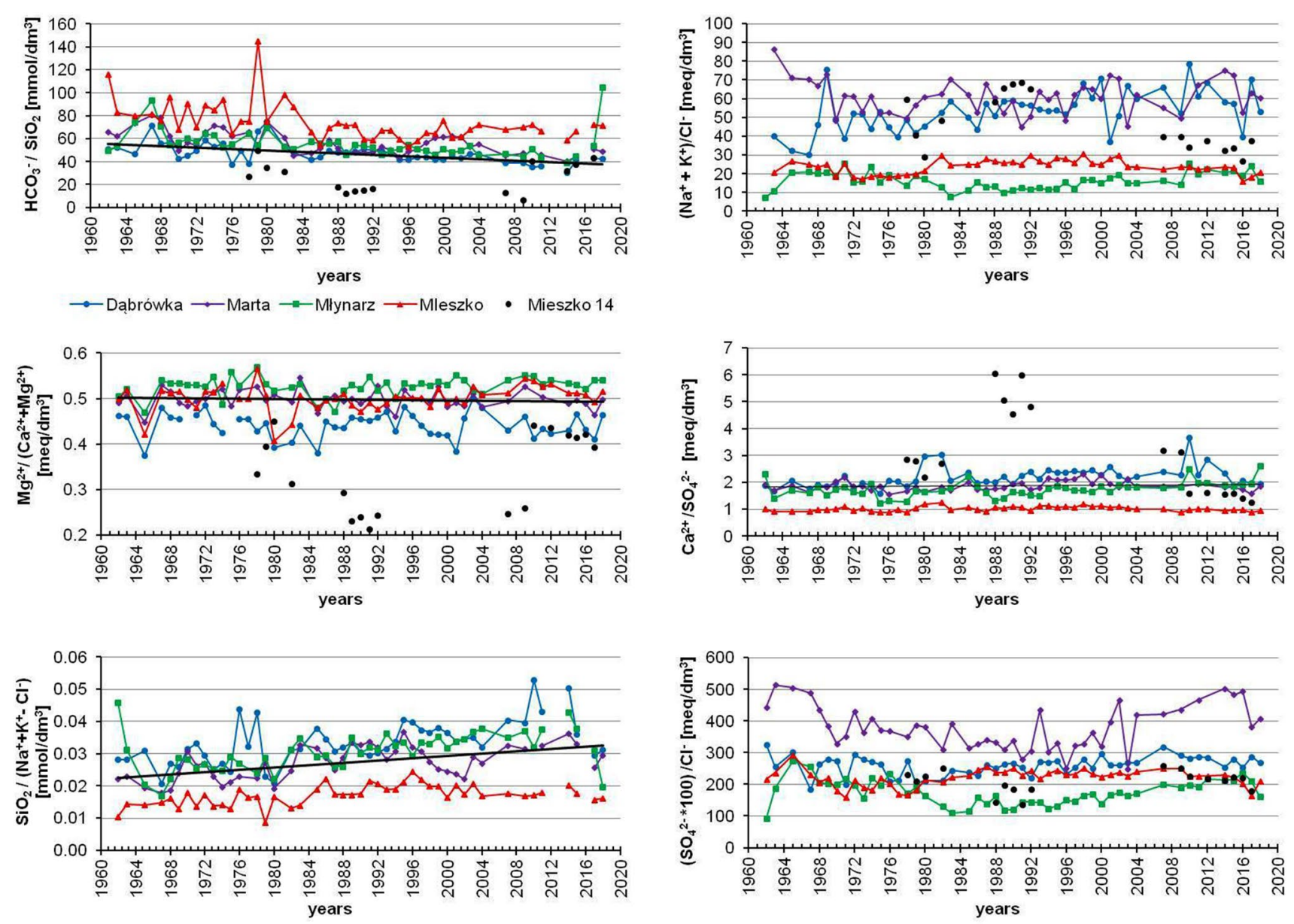

Fig. 4 The long-term trends of variation of selected ionic ratios in mineral waters of Szczawno-Zdrój (data from 1962 to 2018). The approximate characteristic trend lines for spring waters are marked on the graphs. For more explanations, see the text

Calcite dissolution : $2 \mathrm{CaCO}_{3}+2 \mathrm{CO}_{2}+2 \mathrm{H}_{2} \mathrm{O} \rightarrow 2 \mathrm{Ca}^{2+}+4 \mathrm{HCO}_{3}^{-}$,

Dolomite dissolution : $\mathrm{CaMg}\left(\mathrm{CO}_{3}\right)_{2}+2 \mathrm{CO}_{2}+2 \mathrm{H}_{2} \mathrm{O}$

$$
\rightarrow \mathrm{Ca}^{2+}+\mathrm{Mg}^{2+}+4 \mathrm{HCO}_{3}^{-} \text {. }
$$

As can be seen (Eqs. 2 and 3), dissolution of carbonates releases $\mathrm{HCO}_{3}{ }^{-}, \mathrm{Ca}^{2+}$ and even $\mathrm{Mg}^{2+}$ ions (in case of dolomite) into the water. All spring waters contain considerable amounts of natural $\mathrm{CO}_{2}$ gas in the range of $0.6-2.4 \mathrm{~g} \mathrm{dm}^{-3}$ which increases acidity of water and its reactivity in relation to carbonate minerals. The concentration of $\mathrm{CO}_{2}$ in water from spring Mieszko 14 is between 0.2 and $0.67 \mathrm{~g} \mathrm{dm}^{-3}$, which corresponds with the lowest $\left[\mathrm{HCO}_{3}{ }^{-} / \mathrm{SiO}_{2}\right]$ ratio. As can be seen in Fig. 4, the $\left[\mathrm{HCO}_{3}{ }^{-} / \mathrm{SiO}_{2}\right]$ ratios for spring waters revealed considerable variation in time and slight gradual decrease during the observation period from 1962 to 2018. The decrease of this ratio corresponds to the decrease of free $\mathrm{CO}_{2}$ gas content in waters and increase of $\mathrm{SiO}_{2}$ concentration (Fig. 5).
The ratio of $\left[\mathrm{Mg}^{2+} /\left(\mathrm{Ca}^{2+}+\mathrm{Mg}^{2+}\right)\right]$, expressed in meq $\mathrm{dm}^{-3}$, can be used to better understand the role of limestone and dolomite in carbonates weathering and to assess which carbonate minerals undergo dissolution to a greater extent. When $\left[\mathrm{HCO}_{3}{ }^{-} / \mathrm{SiO}_{2}\right]>10$, which is the case of the mineral waters studied, the values of the $\left[\mathrm{Mg}^{2+}\right.$ / $\left.\left(\mathrm{Ca}^{2+}+\mathrm{Mg}^{2+}\right)\right]$ ratio equal to 0.5 indicate dolomite weathering; the values of this ratio below 0.5 suggest limestone (i.e., mainly calcite) dissolution, and above 0.5 -dolomite dissolution or calcite precipitation (Drever 1982; Hem 1989; Hounslow 1995). As can be seen in Table 3 and Fig. 4, for all spring waters in Szczawno-Zdrój, this ratio fluctuates in the range of $0.38-0.57$ suggesting that processes of dissolution/ precipitation of both calcite and dolomite may take place in hydrogeological system. For waters of Dąbrówka spring, the $\left[\mathrm{Mg}^{2+} /\left(\mathrm{Ca}^{2+}+\mathrm{Mg}^{2+}\right)\right]$ ratio revealed in majority values below 0.5 which indicates domination of limestone (mainly calcite) dissolution as a major source of $\mathrm{Ca}^{2+}$ in water. Such geochemical conditions occur also in water from the shallowest spring Mieszko 14 which had the lowest values of 
Fig. 5 Fluctuations in content of $\mathrm{CO}_{2}$ gas and $\mathrm{SiO}_{2}$ over time in mineral waters of SzczawnoZdrój spa. The approximate linear regression curve (black lines in each plot) shows the main trends of change in concentration of both compounds in spring waters
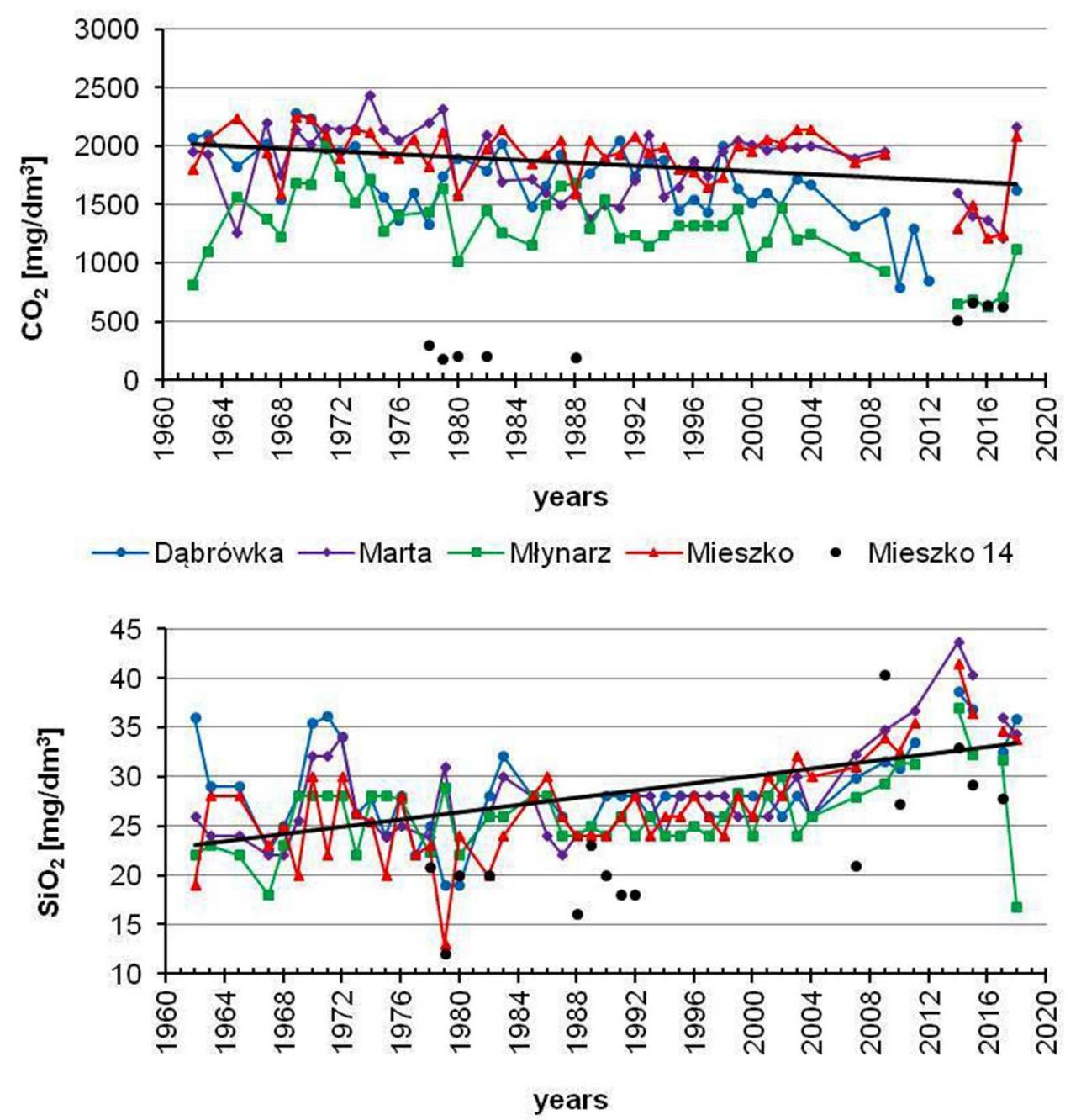

this ratio in the range between 0.21 and 0.45 . On the other hand, in water of Młynarz spring, the $\left[\mathrm{Mg}^{2+} /\left(\mathrm{Ca}^{2+}+\mathrm{Mg}^{2+}\right)\right]$ ratio revealed in majority values above 0.5 suggesting dolomite dissolution or calcite precipitation as major processes responsible for $\mathrm{Mg}^{2+}$ and $\mathrm{Ca}^{2+}$ concentration in water. The possible extensive dolomite dissolution by this waters is corroborated by the highest concentrations of $\mathrm{Mg}^{2+}$ in comparison to other mineral waters (Tab. 3, Fig. 2). As can be seen on Fig. 4, the long-term variations of $\left[\mathrm{Mg}^{2+} /\left(\mathrm{Ca}^{2+}+\mathrm{Mg}^{2+}\right)\right]$ ratio in mineral waters were irregular, oscillated between values of 0.38 and 0.57 and showed no clear increasing or decreasing trends for particular intake. The least mineralized water from the shallowest spring Mieszko 14 revealed the largest range of fluctuations of this ratio, with the lowest values reported between years 1987 and 2009 based on the available set of data. However, it must be stressed that spring Mieszko 14 was not in regular use by the spa.

The ionic ratio of $\left[\mathrm{SiO}_{2} /\left(\mathrm{Na}^{+}+\mathrm{K}^{+}-\mathrm{Cl}^{-}\right)\right]$, expressed in $\mathrm{mmol} \mathrm{dm} \mathrm{dm}^{-3}$, is considered to reflect ion exchange between water and clay minerals or the hydrolysis of alkali feldspars mainly albite, orthoclase (Hem 1989; Hounslow 1995). This index indicates the ratio of the so-called nonhalite sodium (i.e., the amount of $\mathrm{Na}^{+}$which is not compensated by $\mathrm{Cl}^{-}$) to $\mathrm{SiO}_{2}$ and helps to explain the possible sources of silica and sodium dissolved in groundwater. An excess of silica over non-halite sodium most probably indicates the weathering of granite or basalt. Values of this ratio between 1 and 2, i.e., $\mathrm{SiO}_{2}>\left(\mathrm{Na}^{+}+\mathrm{K}^{+}-\mathrm{Cl}^{-}\right)$and $\mathrm{SiO}_{2}<2 *\left(\mathrm{Na}^{+}+\mathrm{K}^{+}-\mathrm{Cl}^{-}\right)$, indicate that the hydrolysis of alkali feldspars may be the main process of incorporation of $\mathrm{Na}^{+}$ions into the solution. In mineral waters extracted by springs (except the spring Mieszko 14), the $\mathrm{SiO}_{2}$ concentrations are less than that of non-halite sodium and the values of $\left[\mathrm{SiO}_{2} /\left(\mathrm{Na}^{+}+\mathrm{K}^{+}-\mathrm{Cl}^{-}\right)\right]$ratio were always below 1 and fluctuated in the range from 0.01 to 0.05 . The lowest values between 0.01 and 0.02 were observed in water of $\mathrm{HCO}_{3}-\mathrm{Na}$ type from spring Mieszko, which is the most saline water in Szczawno-Zdrój and contains the largest amounts of $\mathrm{Na}^{+}$in comparison to other waters (see Fig. 2). Such low values of this ratio strongly suggest that 
ion exchange processes between water and clay minerals may be the dominant source of most of the excess sodium. In case where montmorillonitic clays are present in the aquifer rocks the natural softening may occur, causing that both the $\mathrm{Ca}^{2+}$ and $\mathrm{Mg}^{2+}$ ions can be removed from water to some extent and replaced by $\mathrm{Na}^{+}$(Hounslow 1995; Appelo and Postma 1996; Porowski 2006a, b):

$2 \mathrm{Na}-$ Clay $+\mathrm{Ca}^{2+} \rightarrow 2 \mathrm{Na}^{+}+\mathrm{Ca}-$ Clay.

More complicated scenario can be seen for water extracted from the shallowest spring Mieszko 14 where $\left[\mathrm{SiO}_{2} /\left(\mathrm{Na}^{+}+\mathrm{K}^{+}-\mathrm{Cl}^{-}\right)\right]$ratio fluctuated in much wider range from 0.02 to 1.73 (Table 3 , Fig. 6): such values indicate the possibility of periodic change of some physicochemical features of water which facilitate the hydrolysis of alkali feldspars which can be the source of alkali metals in this water.

Exemplary chemical reactions associated with dissolution of albite or orthoclase to form the most common weathering products - clay minerals such as montomorillonite and kaolinite, can be shown as follows:

$$
\begin{aligned}
& 2 \mathrm{NaAlSi}_{3} \mathrm{O}+2 \mathrm{CO}_{2}+6 \mathrm{H}_{2} \mathrm{O} \rightarrow \mathrm{Al}_{2} \mathrm{Si}_{4} \mathrm{O}_{10}(\mathrm{OH})_{2} \\
& \quad+2 \mathrm{Na}^{+}+2 \mathrm{HCO}_{3}^{-}+2 \mathrm{H}_{4} \mathrm{SiO}_{4}, \\
& 2 \mathrm{KAlSi}_{3} \mathrm{O}_{8}+2 \mathrm{CO}_{2}+11 \mathrm{H}_{2} \mathrm{O} \rightarrow \mathrm{Al}_{2} \mathrm{Si}_{2} \mathrm{O}_{5}(\mathrm{OH})_{4} \\
& \quad+2 \mathrm{~K}^{+}+2 \mathrm{HCO}_{3}^{-}+4 \mathrm{H}_{4} \mathrm{SiO}_{4} .
\end{aligned}
$$

The changes in waters' $\mathrm{pH}$ may be one of the main factors affecting the variations of $\mathrm{m}\left[\mathrm{SiO}_{2} /\left(\mathrm{Na}^{+}+\mathrm{K}^{+}-\mathrm{Cl}^{-}\right)\right]$ratio of studied mineral waters (Fig. 6). Speciation of dissolved silica in groundwater is $\mathrm{pH}$ dependent: the more alkaline environment the more $\mathrm{SiO}_{4}{ }^{2-}$ ions dissolved in water; whereas in more acidic environment, the silicic acid $\left(\mathrm{H}_{4} \mathrm{SiO}_{4}\right)$ dominates, becoming a source of colloidal silica $\left(\mathrm{SiO}_{2}\right)$ (Hounslow 1995; Appelo and Postma 1996). Moreover, the natural increase of alkalinity of groundwater is directly connected with hydrolysis of carbonates, which is the case of mineral water studied. As can be seen on Figs. 4 and 6, the increase
Fig. 6 Fluctuations of $\mathrm{pH}$ values over time in mineral waters of Szczawno-Zdrój spa. The peaks of $\mathrm{pH}$ correlates with the highest values of $\left[\mathrm{SiO}_{2}\right]$ $\left.\left(\mathrm{Na}^{+}+\mathrm{K}^{+}-\mathrm{Cl}^{-}\right)\right]$
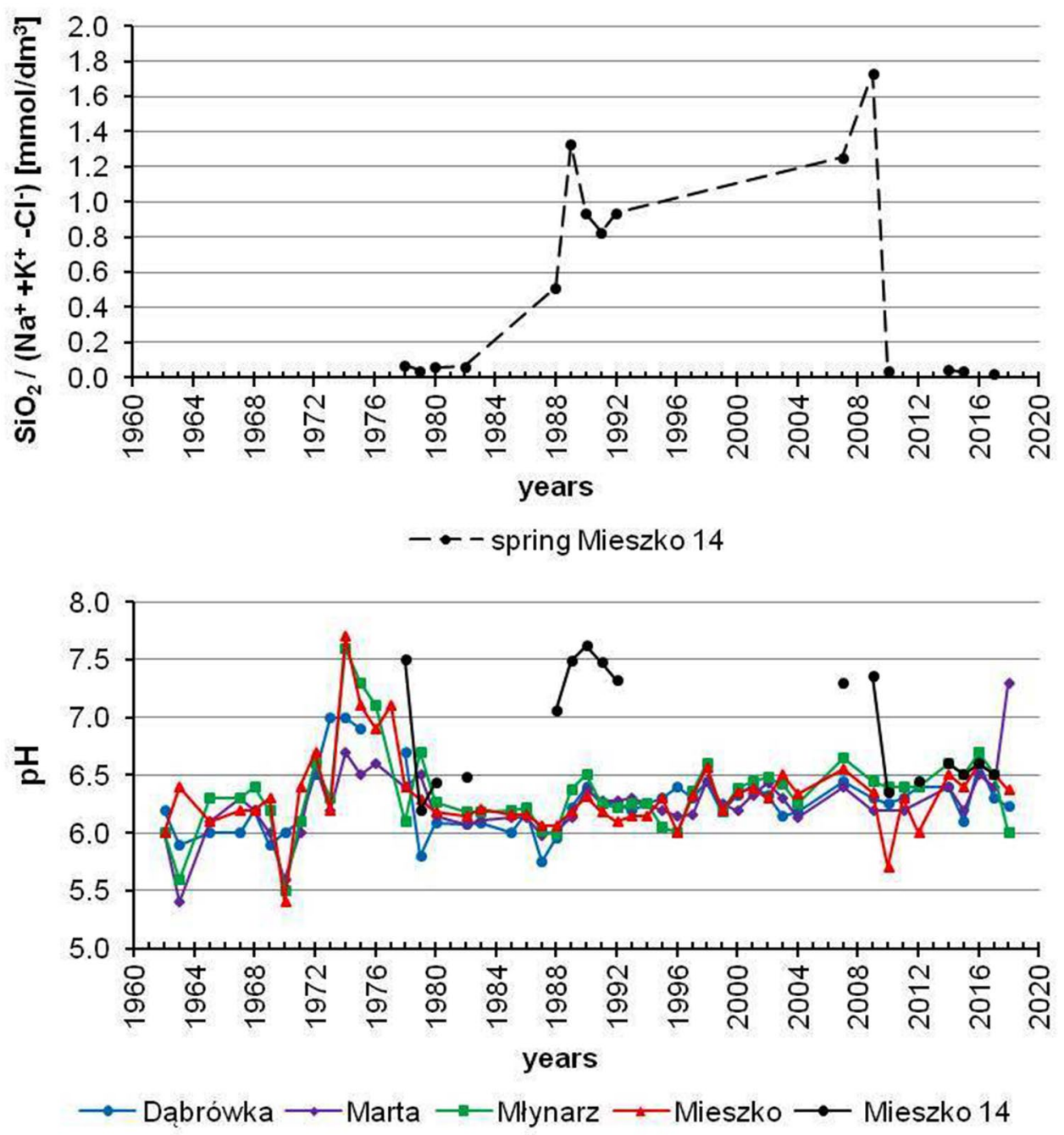
of $\mathrm{pH}$ correlates with the highest values of calculated $\left[\mathrm{SiO}_{2} /\right.$ $\left.\left(\mathrm{Na}^{+}+\mathrm{K}^{+}-\mathrm{Cl}^{-}\right)\right]$.

As can be seen on Fig. 4, the long-term distribution of $\left[\mathrm{SiO}_{2} /\left(\mathrm{Na}^{+}+\mathrm{K}^{+}-\mathrm{Cl}^{-}\right)\right]$values showed an increasing trend since the 60s (i.e., from 1966) up to the beginning of the last decade - presumably up to 2010-2015; from that period the values of this ratio started to decrease to their initial values observed in the $60 \mathrm{~s}$. The most clearly such trend can be observed in case of water from the shallowest spring Mieszko 14: the decrease to the initial values started here in 2010 after the last maximum (as follows from the available data; Fig. 6). Such trend of change of the considered ratio is reflected in mineral waters from all studied sites. The increase of the values of this ratio was connected first of all with the gradual increase of $\mathrm{SiO}_{2}$ concentration (see Fig. 5) and more or less mutually correlated fluctuations in concentration of other ions within limits that did not exceed the initially observed values of the 60s.

The $\left[\mathrm{Na}^{+}+\mathrm{K}^{+} / \mathrm{Cl}^{-}\right]$ratio, expressed in meq $\mathrm{dm}^{-3}$, is usually applied for preliminary identification of the origin of chloride-sodium salinity in groundwater. The sources of chlorides are generally limited in the geological environment to direct water contact with evaporites or mixing with seawater. The $\mathrm{Cl}^{-}$behaves conservatively in the majority of hydrogeochemical processes connected with water evaporation or dilution/mixing as well as interaction with rocks (Carpenter 1978; Hem 1989; Hounslow 1995; Appelo and Postma 1996; Porowski 2001b, 2006a, b). The $\left[\mathrm{Na}^{+}+\mathrm{K}^{+} /\right.$ $\mathrm{Cl}^{-}$] ratio typical for the average composition of the ocean water is around 0.87 (assuming: $\mathrm{Na}^{+}=\mathrm{Na}^{+}+\mathrm{K}^{+}$). This value remains constant during the simple dilution of ocean water or its subaerial evaporation until halite starts to precipitate (Carpenter 1978). The same value of this ratio is a characteristic for meteoric water originating mainly from seawater aerosols. However, the primary source of chloride in shallow groundwater usually is the dissolution of sodium chloride $(\mathrm{NaCl})$. The values of this ratio close to 1.0 indicate that the chloride salinity originates from dissolution of chloride evaporites, mainly halite, which can be formed during various processes of evaporation of meteoric water or groundwater in the hydrological cycle. As can be seen in Table 3 and Fig. 4, the $\left[\mathrm{Na}^{+}+\mathrm{K}^{+} / \mathrm{Cl}^{-}\right]$ratio in studied mineral waters was very high within the entire observation period and varied in the range from 7.0 to 86.1. Such high excess of $\mathrm{Na}^{+}$(together with $\mathrm{K}^{+}$, as alkali metals) indicates the occurrence of non-halite sodium in great amounts. Usually, it is assumed that non-halite sodium originates from aluminosilicates weathering (mainly albite) or ion exchange reactions with clay minerals: in this case, first of all, natural softening (see Eq. 4) may be responsible for incorporation of sodium ions into the water. The values of this ratio corroborate the previous conclusions derived from $\left[\mathrm{SiO}_{2}\right]$ $\left.\left(\mathrm{Na}^{+}+\mathrm{K}^{+}-\mathrm{Cl}^{-}\right)\right]$ratio.
The long-term variation of $\left[\mathrm{Na}^{+}+\mathrm{K}^{+} / \mathrm{Cl}^{-}\right]$ratios in mineral waters of Szczawno-Zdrój revealed rather horizontal trends formed by two water groups in a different range of values (Fig. 3): in waters from springs Dąbrówka and Marta, values of this ratio varied in wide range from 30 to 86.1; whereas in waters from springs Młynarz and Mieszko, this ratio changed in much more narrow range from 7.0 to 30.7 ; groundwater extracted from the shallowest spring Mieszko 14 revealed this ratio is in the range of 26.7-68.7 which is closure to waters of Dąbrówka and Marta.

The $\left[\mathrm{Ca}^{2+} / \mathrm{SO}_{4}{ }^{2-}\right]$ ratio, expressed in meq $\mathrm{dm}^{-3}$, helps to explain the sources of calcium and sulfates and to identify the occurrence of processes connected with dissolution of gypsum (or anhydrite) and/or the neutralization of acidulous waters by limestone or dolomite. Primary source of sulfate $\left(\mathrm{SO}_{4}{ }^{2-}\right)$ in groundwater is usually minerals such as pyrite $\left(\mathrm{FeS}_{2}\right)$, gypsum $\left(\mathrm{CaSO}_{4} * 2 \mathrm{H}_{2} \mathrm{O}\right)$ or anhydrite $\left(\mathrm{CaSO}_{4}\right)$, as well as organic sulfur compounds formed during the combustion of fossil fuels and incorporated into groundwater via rainfall or snow melt (Drever 1982; Hounslow 1995; Appelo and Postma 1996; Porowski et al. 2019). In hydrogeological conditions where there is no intensive carbonate dissolution, the gypsum dissolution can be identified by relatively equal concentrations of $\mathrm{Ca}^{2+}$ and $\mathrm{SO}_{4}{ }^{2-}$ in water, which give a value of $\left[\mathrm{Ca}^{2+/} \mathrm{SO}_{4}{ }^{2-}\right]$ ratio close to 1.0. In a geological environment where carbonates are present in aquifer rocks, which is the case of the sandstone and conglomerates of Szczawno-Zdrój, it is not possible to distinguish gypsum dissolution due to an excess of $\mathrm{Ca}^{2+}$ coming from dissolution of limestone. As can be seen in Table 3 and Fig. 4, all mineral waters in Szczawno-Zdrój (including water from the shallowest spring Mieszko 14) revealed values of $\left[\mathrm{Ca}^{2+} /\right.$ $\mathrm{SO}_{4}{ }^{2-}$ ] ratio in the range of $0.9-6.0$ which suggests that processes of limestone dissolution as well as gypsum may be present in hydrogeological system. In waters extracted by springs Dąbrówka, Marta, Młynarz and Mieszko 14, the ratios of $\left[\mathrm{Ca}^{2+} / \mathrm{SO}_{4}{ }^{2-}\right]$ were always above 1.2 which indicates excess of $\mathrm{Ca}^{2+}$ and possible source of calcium other than gypsum-here it is limestone as was inferred from other ionic ratios. In water from spring Mieszko, this ratio varied between 0.9 and 1.2, which strongly suggests that possible dissolution of gypsum cannot be excluded: this water has the highest mineralization (i.e., TDS from 2.5 to $4.2 \mathrm{~g} \mathrm{dm}^{-3}$; see Tab. 1) and concentration of $\mathrm{SO}_{4}{ }^{2-}$ varied in the range $210-330 \mathrm{mg} \mathrm{dm}^{-3}$. The most probable sources of $\mathrm{SO}_{4}{ }^{2-}$ in studied mineral waters may be (Cook and Herczeg 2000): (1) atmospheric sulfates- $\mathrm{SO}_{4}{ }^{2-}$ contained in recharge meteoric waters, (2) reduced inorganic sulfur compounds (RIS) dispersed in fine-grained sedimentary rocks, mostly in the form of pyrite, which undergo oxidation during rock weathering, and finally (3) gypsum, which may form during local evaporation processes or can be contained in geological environment along the groundwater 
circulation paths. To corroborate the origin of sulfates in mineral waters, the isotopic composition of sulfur $\left({ }^{34} \mathrm{~S} /{ }^{32} \mathrm{~S}\right.$ expressed as $\left.\delta^{34} \mathrm{~S}\right)$ and oxygen $\left({ }^{18} \mathrm{O} /{ }^{16} \mathrm{O}\right.$ expressed as $\left.\delta^{18} \mathrm{O}\right)$ of dissolved $\mathrm{SO}_{4}{ }^{2-}$ were analyzed in 2018 in water from springs Mieszko, Dąbrówka, Marta and Młynarz. The results showed that isotopic composition of $\mathrm{SO}_{4}{ }^{2-}$ dissolved in studied waters ranged from +11.7 to $+13.0^{\circ} \%$ for $\delta^{34} \mathrm{~S}$ and from +10.2 to $+11.3 \%$ for $\delta^{18} \mathrm{O}$. Such isotopic composition is typical for sulfates originating most likely from the lithogenic sources, mainly dissolution of evaporitic gypsum which may be formed in the aquifer's vadose zone or can be also present in aquifer rocks; dissolution of RIS compounds is not evident or can be negligible (Cook and Herczeg 2000; Porowski et al. 2019). The time distribution of $\left[\mathrm{Ca}^{2+} / \mathrm{SO}_{4}{ }^{2-}\right]$ values showed rather horizontal trend since the 60 s to last years.

The $\left[\left(\mathrm{SO}_{4}{ }^{2-} \times 100\right) / \mathrm{Cl}^{-}\right]$ratio, expressed in meq $\mathrm{dm}^{-3}$, usually is used as an indicator of the character of the geologic environment of groundwater occurrence (Razowska 1999; Porowski 2006a, b; Macioszczyk and Dobrzyński 2007). Low values of this ratio, below 1.0 and 10.0, indicate a strongly reducing environment. Values within the range of several tens and more are characteristic for shallow meteoric waters in the active exchange zone in an oxidizing environment. As can be seen in Table 3 and Fig. 4, during the entire monitoring period, the mineral waters in Szczawno-Zdrój had this ratio in the range of high values between 90.8 and 513.5, which corroborates predominance of oxidizing environment of groundwater flow.

As can be seen from Figs. 2 and 4, the time distributions of TDS values and concentrations of major ions dissolved in waters of Szczawno-Zdrój show a characteristic "concave" shape: the decreasing trend begins in the late1960s and continues until the late 1990s, reaching the lowest values around 1996-1998 (depending on the spring), then the TDS values and major ion concentrations start to rise and the upward trend continues generally to present days. In such long-term trend, the shorter periods of strong variation of concentration of major ions can be also observed. This "concave" shape trends generally are not reflected in time distribution of ionic ratios (except of $\left[\left(\mathrm{SO}_{4}{ }^{2-} \times 100\right) / \mathrm{Cl}^{-}\right]$ratio which is the simple concentration ratio) that strongly suggests the occurrence of dilution processes by low mineralized waters. Most likely the observed long-term fluctuations of chemical composition of mineral waters are related to direct influence of the primary climatic factors, namely the amounts of atmospheric precipitation and its annual distribution in particular seasons. The statistical analysis of correlation between springs discharge in Szczawno-Zdrój and monthly mean of atmospheric precipitation made previously by Liber-Madziarz and Filbier (2001) revealed the immediate or postponed (from 0 to 10 months depending on the spring and the observation period) reaction of springs discharge to rainfall events. Moreover, a detailed observations of the chemical composition of mineral waters in Szczawno-Zdrój after flood in Poland in 1997 showed clear positive impact of the increased amount of precipitation on the springs discharge along with a decrease of water mineralization (Kiełczawa et al. 2008; Kiełczawa and Liber-Makowska 2018).

The long-term observations of meteorological data on atmospheric precipitation in Poland show rather high annual variability of precipitation amounts and existence of wet and dry periods; such wet periods with increased annual rainfall totals were observed for example in the years 1971-1981 and 1993-2000 (Kossowska-Cezak et al. 2000; ZiernickaWojtaszek 2006). To illustrate in more detail the distribution of precipitation in the area of studied springs, the archival precipitation records were obtained from the meteorological station in Szczawno-Zdrój (location: $\phi=50^{\circ} 48^{\prime} 24^{\prime \prime} \mathrm{N}$, $\lambda=16^{\circ} 14^{\prime} 28^{\prime \prime} \mathrm{E}, h=431 \mathrm{~m}$ a.s.l.) belonging to the national network of the Institute of Meteorology and Water Management-National Research Institute (IMGW-PIB). The compilation of the annual precipitation totals for the years 1956-2019 is plotted in Fig. 7 against the long-term distribution of TDS values of mineral waters from studied springs (Fig. 7a).

As can be seen on Fig. 7, these two wet periods of increased annual precipitation characteristic for Poland (i.e., for the years 1971-1981 and 1993-2000) are also noticed on the precipitation data recorded in Szczawno-Zdrój and both of them quite well coincide with the periods of decreasing TDS values (and concentration of major chemical compounds) of mineral waters. It should be stressed that presented correlation is only demonstrative and shows an approximate relationship between mean annual precipitation totals (i.e., continuous observations from the whole year) and chemical analyses of mineral waters made only once a year, usually during summer season. The effective impact of rainfall events on the spring discharge and, in consequence, on the degree of dilution of the spring's mineral water depend not only on the precipitation amounts but also on the intensity of rain and its duration in time. Such rainfall intensity is reflected by the frequency of days with precipitation in particular classes of daily sums defined as: $0.1 \mathrm{~mm}$, $1.0 \mathrm{~mm}, 5.0 \mathrm{~mm}, 10 \mathrm{~mm}$ and $30 \mathrm{~mm}$ (Fig. 7b). Usually, rainfalls with high intensity may affect spring discharge in less degree, especially in mountainous areas, because large amounts of water reaching ground surface in quite short period of time undergoes surface run-off in greater extent. As can be seen on Fig. 7b, a long-term distributions of the annual frequencies of days with smaller amounts of daily sums of precipitation, i.e., $\geq 0.1$ and $\geq 1.0 \mathrm{~mm}$, show better 
Fig. 7 Relationship between the long-term distribution of TDS values of studied mineral waters and the total annual precipitations recorded at meteorological station in Szczawno-Zdrój (a). The frequency of days with precipitation amounts in selected classes of daily sums $(\mathrm{mm})$ is shown for reference to better understand the distribution of rainfalls; the abbreviation " $>=$ " means greater or equal. Rainfall data were obtained from the Institute of Meteorology and Water Management-National Research Institute (IMGW-PIB) in Wrocław, Poland. For additional explanations, see the text
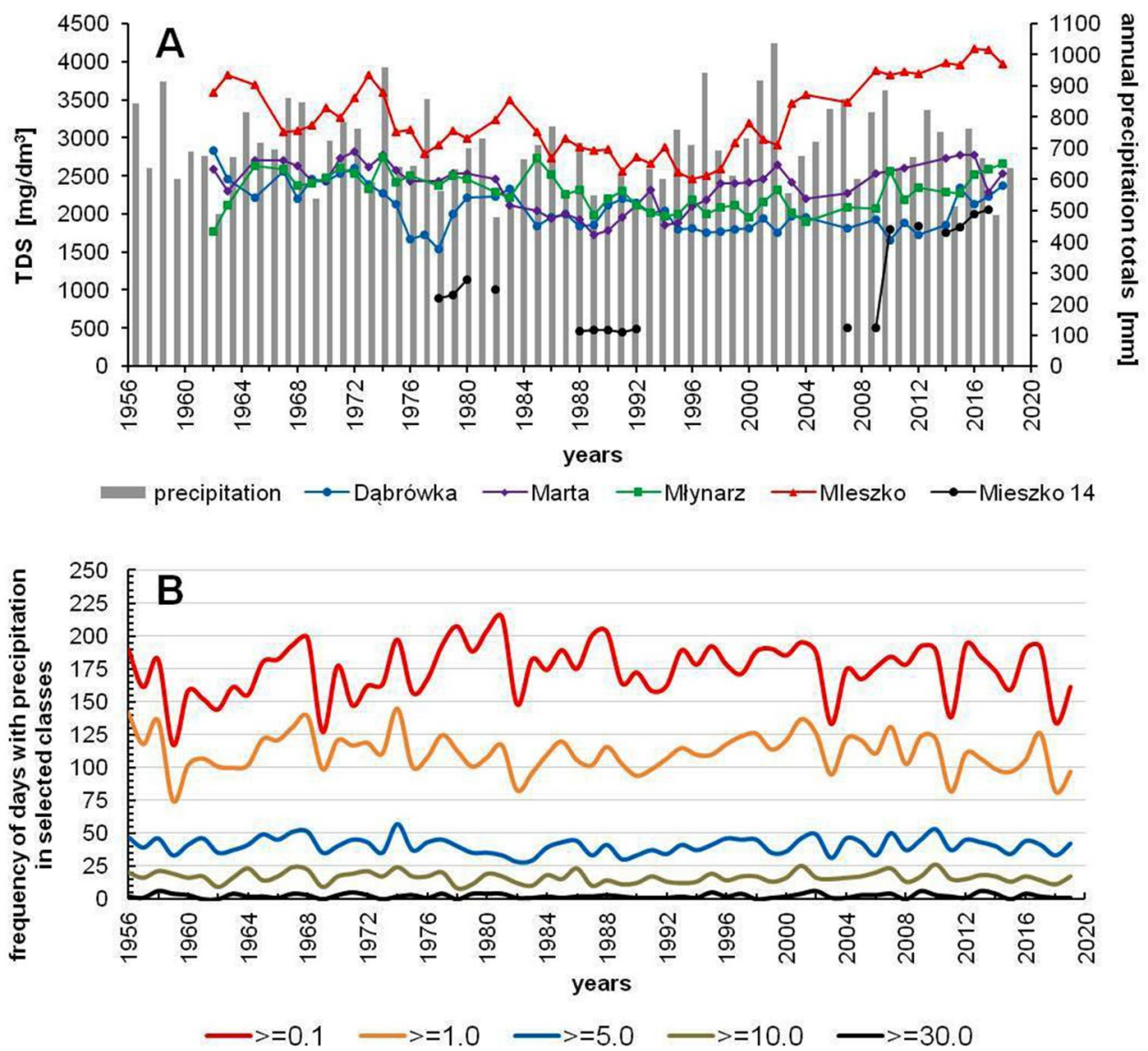

negative correlation with this "concave" shape distribution of TDS values of mineral waters. The simple dilution of chemical composition of mineral waters by the periodic influx of low mineralized rain or snow melt water generally does not affect the values of ionic ratios which remain constant, i.e., their time distribution trend remains more or less horizontal. In case when the concentration of a given chemical compound is more sensitive on the influence of additional factors (e.g., pH, redox conditions, equilibrium in water-mineral system), we can observe some respective change in values of ionic ratio, which is very helpful in prediction of water-rock interaction trends and possible evolution of chemical composition of groundwaters.

\section{Conclusions}

The archival records of chemical composition of mineral waters in Szczawno-Zdrój spa were analyzed in terms of variation of ionic ratios as well as individual elements to explain the sources of the major compounds dissolved in water and the origin and evolution of groundwater chemical composition in time. The analyzed data related to waters discharged by five main intakes (i.e., springs-Dąbrówka,
Marta, Młynarz, Mieszko and Mieszko 14) and contained the longest available series of chemical records from 1962 to 2018 .

The research showed that mineral waters in SzczawnoZdrój belong to shallow meteoric $\mathrm{CO}_{2}$-rich, Rn-containing groundwaters which circulate in Carboniferous sediments and form their chemical composition mainly through the interactions with aquifer rocks. Detailed analysis of longterm variations of ionic ratios revealed two major types of geochemical processes which seems to play a fundamental role in formation of the chemical composition of studied waters: (1) the carbonates weathering-mostly acid hydrolysis of limestones and dolomites, and (2) the ion exchange reactions with clay minerals-mainly the so-called natural softening, which is responsible for incorporation of alkali metal ions (mostly $\mathrm{Na}^{+}$) into the water. Both types of processes are responsible for the occurrence of dominant ions in waters such as $\mathrm{Ca}^{2+}, \mathrm{Mg}^{2+}, \mathrm{Na}^{+}$, and $\mathrm{HCO}_{3}{ }^{-}$. As can be inferred from ionic ratios, the aluminosilicate hydrolysis also occurs with variable extent, but played rather the secondary role as a source of major compounds in studied waters. Chloride mineralization is low and most probably is connected with atmospheric precipitation or direct dissolution of halite (in less extent) formed during local evaporation of water. Sulfates in studied waters may come from different 
sources: (1) first of all lithogenic sources: mainly dissolution of evaporitic gypsum which may be formed during local evaporation processes or can be also present in aquifer rocks and (2) atmospheric sulfates, i.e., $\mathrm{SO}_{4}{ }^{2-}$ contained in recharge meteoric waters. An important role in considerable fluctuations of chemical composition of mineral waters in time plays the clearly observed trends of decreasing of $\mathrm{CO}_{2}$ content, increasing $\mathrm{SiO}_{2}$ concentration and considerable fluctuation of $\mathrm{pH}$. Especially the $\mathrm{CO}_{2}$ decrease and temporal $\mathrm{pH}$ fluctuations may influence on the scenario of water-rock interaction processes.

The time distributions of total mineralization values and concentration of individual major compounds dissolved in mineral waters showed a characteristic "concave" shapes which are not reflected in time distribution of ionic ratios. Such fluctuations of chemical composition of mineral waters in Szczawno-Zdrój are related to the influence of primary climatic factors, first of all the amounts of atmospheric precipitation and its annual distribution in particular seasons. This is corroborated by the long-term observations of atmospheric precipitation obtained from the meteorological station in Szczawno-Zdrój. The distinguished two wet periods with increased annual rainfall totals in the years 1971-1981 and 1993-2000 coincide well with the periods of reduced mineralization of spring waters and corresponding decrease of concentrations of major ions. Moreover, the influence of rainfall events on the mineral water dilution is more effective in the years when the annual frequency of days with small amounts of daily sums of precipitation (i.e., $\geq 0.1 \mathrm{~mm}$ and $\geq 1.0 \mathrm{~mm}$ according to precipitation classes) is high. It means that, especially in mountainous areas, large amounts of water reaching ground surface in quite short period of time undergoes surface run-off in greater extent.

Such mutual relations between atmospheric precipitation, spring discharge and their mineralization and chemical composition indicate rather strong vulnerability of mineral waters to climate change and eventual pollution of rainwater and the atmosphere. The issues connected with vulnerability of medicinal and curative waters in similar balneological resorts need further detailed studies to assess the range of environmental and hydrogeological hazards and elaborate effective mitigation procedures.

Acknowledgements We would like to thank for the authorities of Uzdrowisko Szczawno-Jedlina S.A. for providing access to the archival records of chemical analysis of mineral waters. The Institute of Meteorology and Water Management-National Research Institute (IMGW-PIB) in Wroclaw is thanked for providing the archival precipitation records from meteorological station in Szczawno-Zdrój. This work was supported by National Science Centre Poland, grant number UMO-2015/17/B/ST/10/03295.

Author contributions AR: conceptualization, investigation, hydrogeochemical data curation, validation, visualization, software, writing — original draft, writing — revised draft. AP (corresponding author): conceptualization, investigation, methodology, software, writingoriginal draft, writing-revised draft, editing, funding acquisition. TZ: long-term records of hydrochemical data providing, data validation and compilation, writing hydrogeological and geological sections, data interpretation. $\mathrm{AD}$ : long-term records of atmospheric precipitation providing, compilation, calculation, visualization and interpretation of meteorological data, editing.

Funding This work was supported by National Science Centre Poland, grant number UMO-2015/17/B/ST/10/03295.

Availability of data and material Not applicable.

\section{Declarations}

Conflict of interest The authors declare that they have no competing interests.

Open Access This article is licensed under a Creative Commons Attribution 4.0 International License, which permits use, sharing, adaptation, distribution and reproduction in any medium or format, as long as you give appropriate credit to the original author(s) and the source, provide a link to the Creative Commons licence, and indicate if changes were made. The images or other third party material in this article are included in the article's Creative Commons licence, unless indicated otherwise in a credit line to the material. If material is not included in the article's Creative Commons licence and your intended use is not permitted by statutory regulation or exceeds the permitted use, you will need to obtain permission directly from the copyright holder. To view a copy of this licence, visit http://creativecommons.org/licenses/by/4.0/.

\section{References}

Appelo CAJ, Postma D (1996) Geochemistry, groundwater and pollution, 2nd edn. A.A, Balkema, Rotterdam, 536p

Carpenter AB (1978) Origin and chemical evolution of brines in sedimentary basins. Okla Geol Surv Circular 79:60-77

Ciężkowski W (1990) A study of the hydrogeochemistry of mineral and thermal waters in the Polish Sudets Mts (SW Poland). Pr Nauk Inst Geotech Politech Wrocławskiej Ser Monogr 60:130

Collins A (1975) Geochemistry of oilfield waters. Developments in Petroleum Science, 1. American Elsevier Publishing Comp, New York, $96 \mathrm{p}$

Cook P, Herczeg A (2000) Environmental tracers in subsurface hydrology. Kluwer, Boston

Dowgiallo J (1978) The origin of carbon dioxide in the acidulous waters of the Carpathians and the Sudetes in Poland. Biul Inst Geol 312:191-217

Drever J (1982) The geochemistry of natural waters. Prentice-Hall Inc., Englewood Clifs, $388 \mathrm{p}$

Drobnik M, Latour T (2006) Wody lecznicze występujące w Szczawnicy-możliwości ich wykorzystania do kuracji uzdrowiskowej. [Therapeutic waters occurring in szczawnica - the possibilities of their use in treatment.]. Balneol Pol 1:40-45

Fistek J, Iwanowski S, Iciek A, Jagodziński A (1975) Geological, geophysical and hydrogeological research as an example of a complex approach to the problem of medicinal water prospecting in the Sudety Mountains health resorts. Biul Inf Geofiz 1:5-30

Fistek J, Tęsiorowska H, Starzyńska D (1972) Sprawozdanie z I-go etapu badań geologicznych wykonanych w rejonie Szczawna Zdroju wraz z projektem na wykonanie II-go etapu prac /wierceń/. 
[Hydrogeological report from the first stage of geological research in Szczawno Zdrój]. Warszawa-Wrocław

Haydukiewicz A, Olszewski S, Porębski S, Teisseyre A (1982) Detailed geological map od the Sudetes Mts. scale 1:25000, sheet Wałbrzych, with explanatory notes

Hem JD (1989) Study and interpretation of the chemical characteristics of natural water. Water-supply paper 2254. Department of the Interior. U.S. Geological Survey, Alexandria

Hounslow AW (1995) Water quality data. Analysis and interpretation. 1st edn. CRC Press, Boca Raton, USA, 398 p

Ignatov I, Mosin O, Velikov B, Baue E (2014) Influence of isotopic composition of water with varrying deuterium content in composition with mountain water of bulgaria on human longevity. J Med Physiol Biophys 7:46-78

Kiełczawa B, Liber-Makowska E (2017) Zmienność wybranych parametrów fizykochemicznych wód leczniczych Szczawna-Zdroju (Sudety). [Variability of selected physicochemical parameters of the Szczawno-Zdrój healing waters.]. Prz Geol 65:973-978

Kiełczawa B, Liber-Makowska E (2018) Factors affecting changes in quality parameters of medicinal esters in Szczawno Zdrój (Sudety Mountains, Poland). In: Proceedings 18th international multidisciplinary scientific conference, vol 18, no 3.1 hydrogeology and water resources. SGEM, Albena, Bulgaria

Kiełczawa B, Wojtkowski P, Filbier P (2008) Chosen issues of threats of Szczawno Zdrój medicinal waters. Pr Nauk Inst Górnictwa Politech Wrocławskiej 123:112-120

Kossowska-Cezak U, Martyn D, Olszewski K, Kopacz-Lembowicz M (2000) Meteorologia i Klimatologia. Pomiary, obserwacje, opracowania. PWN, Warszawa-Łódź

Kotarba M (1988) Geochemical criteria of the genesis of gases accumulated in the coal-bearing series of the Upper Carboniferous of Wałbrzych basin. Zesz Nauk AGH 1199 Geol 42:1-119

Latour T, Smętkiewicz K (2012) Właściwości fizykochemiczne i chemiczne wód geotermalnych i ich zastosowanie lecznicze ze szczególnym uwzględnieniem wody z odwiertu PIG/AGH-2 w Uniejowie. [Physical and chemical properties of geothermal water and their use in medicine with a particular focus on well PIG/ AGH-2 in Uniejów]. Biul Uniejowski 1:79-93

Liber-Madziarz E, Filbier P (2001) Reasons of the natural change of the medicinal water discharge of Szczawno spa. In: Bocheńska T, Staśko S (eds) Current problems of hydrogeology X, vol 1. Wrocława University pp 329-338 (in Polish only)

Liber-Makowska E, Kiełczawa B (2018) Influence of water exploitation conditions on variations in the discharge of intakes and selected physicochemical parameters exemplified with thermal medicinal waters of Lądek Zdrój (Sudety Mts., Poland). In: SGEM (ed) Proceedings 18th international multidisciplinary scientific conference, vol 18, no 3.1. Hydrogeology and water resources. Albena, Bulgaria

Macioszczyk A, Dobrzyński D (2007) Hydrogeochemia strefy aktywnej wymiany wód. Wydawnictwa Naukowe PWN, Warszawa

Nawrocki J, Becker A, Gałączka D (2017) Atlas Geologiczny Polski. Państwowy Instytut Geologiczny - Państwowy Instytut Badawczy, Warszawa. $170 \mathrm{p}$

Nielsen DM, Nielsen GL (2006) The essential handbook of groundwater sampling. CRC Press, Boca Raton, USA, 328p
Porowski A, Romanova A, Gebus-Czupyt B, Radzikowska M (2018) Skład izotopowy mineralnych i leczniczych wód butelkowanych polski: analiza porównawcza w świetle parametrów jakościowych i przyrodniczych. Acta Balneol 4:264-271

Porowski A (2001a) Temporal and spatial variability in chemical composition of mineralized from the Iwonicz anticline (SE Poland). Przegl Geol 49(4):317-325

Porowski A (2001b) Chemical composition and origin of ionic ratios in the Iwonicz Anticline mineralized groundwaters (Polish Outer Carpathians). Ann Soc Geol Pol 71:125-134

Porowski A (2006) Origin of mineralized waters in the Central Carpathian Synclinorium, SE Poland. Stud Geol Pol 125:64

Porowski A (2007) Sens i znaczenie badań geotermometrycznych w poszukiwaniach wód termalnych o niskiej entalpii. [Signifficance and use of geothermometric study in exploration of low-enthalpy thermal waters.]. Tech Poszuk Geol Geoterm Zrównoważony Rozw 2:69-77

Porowski A, Dowgiałło J (2009) Application of selected geothermometers to exploration of low-enthalpy thermal water: The Sudetic Geothermal Region in Poland. Environ Geol 58(8):1629-1638

Porowski A, Porowska D, Halas S (2019) Identification of sulfate sources and biogeochemical processes in an aquifer affected by Peatland: Insights from monitoring the isotopic composition of groundwater sulfate in Kampinos National Park. Poland. Water 11(7):1388. https://doi.org/10.3390/w11071388

Przylibski T, Mroczkowski K, Żebrowski A, Filbier P (2001) Radon222 in medical groundwaters of Szczawno Zdrój (Sudety Mountains, SW Poland). Environ Geol 40:429-439

Razowska L (1999) Wskaźniki hydrochemiczne - mało przydatne czy niedoceniane? In: Sadurski A (ed) Współczesne Problemy Hydrogeologii, tom IX. Państwowy Instytut Geologiczny, Kielce, pp 307-313

Teisseyre H (1969) Detailed geological map of the Sudetes Mts, scale 1:25000, sheet Stare Bogaczowice, with explanatory notes

Teisseyre J (1966) The mineral springs of Lower Slesia in light of geological studies. In: Z geologii ziem zachodnich. Sesja naukowa dwudziestolecia polskich badań 1945-1965. Wrocław, pp 485-505

Vinograd N, Porowski A (2020) Application of isotopic and geochemical studies to explain the origin and formation of mineral waters of Staraya Russa Spa. NW Russia. Environ Earth Sci 79:183. https:// doi.org/10.1007/s12665-020-08923-6

Żaczek J, Porowski A (2017) Hydrogeological settings and origin of groundwater composition in the southern part of the gorce MTS, kowaniec mały catchment. Ann Soc Geol Pol 87:183-197. https:// doi.org/10.14241/asgp.2017.008

Ziernicka-Wojtaszek A (2006) Zmienność opadów atmosferycznych na obszarze Polski w latach 1971-2000. In: Trepińska J, Olecki Z (eds) Klimatyczne aspekty środowiska geograficznego. Instytut Geografii i Gospodarki Przestrzennej UJ, Kraków, pp 139-148

Publisher's Note Springer Nature remains neutral with regard to jurisdictional claims in published maps and institutional affiliations. 